\title{
Efektifitas Kepatuhan Terapi Metotreksat melalui Disease Activity Score 28 (DAS28) pada Pasien Artritis Reumatoid
}

\author{
Anisyah Achmad ${ }^{1}$, Bagus P. P. Suryana ${ }^{2}$, Tika Yasmin Rahmayanti ${ }^{1}$ \\ ${ }^{1}$ Departemen Farmasi Klinis, Jurusan Farmasi, Fakultas Kedokteran, Universitas Brawijaya, Malang, Indonesia, \\ ${ }^{2}$ Departemen Reumatologi, Program Studi Kedokteran, Fakultas Kedokteran, Universitas Brawijaya, Malang, \\ Indonesia/RSUD dr.Saiful Anwar, Malang, Indonesia.
}

\section{INFO ARTIKEL}

Sejarah artikel:

Penerimaan

naskah: $\quad 4$

November 2019

Penerimaan

naskah revisi: 20

April 2020

Disetujui untuk dipublikasikan: 28

Mei 2020

\section{Kata kunci :}

Artritis

Reumatoid,

DAS28,

Kepatuhan Terapi,

Metotreksat

\section{A B S T R A K}

Artritis reumatoid (AR) merupakan penyakit autoimun, kronik, dengan inflamasi dan kaku sendi pagi hari > 30 menit serta peningkatan kadar Rheumatoid Factor (RF), laju endap darah (LED), dan C-reaktif protein (CRP). Metotreksat merupakan pengobatan lini pertama untuk AR. Keberhasilan terapi dipantau menggunakan Disease Activity Score 28 (DAS28) yang merupakan pengukuran pada 28 sendi nyeri dan inflamasi. Pengobatan AR bersifat jangka panjang dan kontinyu sehingga dibutuhkan pemantauan terhadap kepatuhan. Tujuan penelitian adalah untuk mengetahui efektifitas kepatuhan terapi metotreksat melalui DAS 28.. Penelitian menggunakan metode potong lintang dengan analisis deskriptif kuantitatif dan kualitatif yang dilakukan di Poli Rawat Jalan Reumatologi Rumah Sakit dr. Saiful Anwar (RSSA) Kota Malang pada bulan Maret-Mei 2018 dan dinyatakan telah laik etik dengan nomor edaran 400/32/K.3/302/2018. Jumlah sampel yang digunakan sebanyak 88 pasien dengan kriteria inklusi lakilaki dan perempuan yang menggunakan metotreksat minimal 3 bulan, dilengkapi dengan data LED tanpa komplikasi Systemic Lupus Erythematosus (SLE), Inflammatory Bowel Disease (IBD) dan kanker. Instrumen yang digunakan adalah kuesioner Morinsky Medication Adherence Scale-8. Analisis statistik menggunakan Rank Sperman Hasil penelitian menunjukkan bahwa $72 \%$ pasien mempunyai tingkat kepatuhan tinggi, $23 \%$ tingkat kepatuhan sedang, dan $5 \%$ mempunyai tingkat kepatuhan rendah. Sebanyak $21 \%$ dari $72 \%$ pasien dengan tingkat kepatuhan tinggi berhasil meraih kondisi remisi sedangkan sisanya masih dalam kondisi aktif.. Hasil Analisa st atistik menunjukkan bahwa kepatuhan terapi metotreksat tidak berhubungan signifikan dengan DAS 28 pada pasien AR $(r=0,148 ; \mathrm{p}=$ $0,169)$. Namun tetap ada remisi pada tingkat kepatuhan yang tinggi. Kepatuhan terapi metotreksat tetap dibutuhkan oleh pasien AR untuk mencapai kondisi remisi.

The Effectiveness of The Methotrexate Medication Adherence toward to Disease Activity 28 (DAS28) in Rheumatoid Arthritis Patients

Keywords:

DAS28,

Medication

Adherence,

Methotrexate,

Rheumatoid

Arthritis

\begin{abstract}
A B S T R A C T
Rheumatoid arthritis (AR) is an chronic autoimmune disease with inflammation and stiff joints in the morning $>30$ minutes and elevated levels of Rheumatoid Factor (RF), sedimentation rate (LED), and C-reactive protein (CRP). Methotrexate is the first-line treatment for AR. The success of therapy was monitored using Disease Activity Score 28 (DAS28) which is a measurement of 28 joints of pain and inflammation. AR treatment takes a long time so it requires monitoring of adherence. The aim of this study was to determine the effectiveness of methotrexate therapy adherence toward to DAS 28. The research uses cross-sectional method with quantitative and qualitative descriptive analysis conducted at Rheumatology Outpatient Poly, Hospital dr. Saiful Anwar (RSSA) of Malang City in March May 2018 and it was stated that ethics was approved with a number 400/32 / K.3 / 302/2018. The subject used was 88 patients with male and female inclusion criteria using methotrexate for at least 3 months, supplemented with LED data without complications from Systemic Lupus Erythematosus (SLE), Inflammatory Bowel Disease (IBD) and cancer. The instrument used was the Morinsky Drug Compliance Scale Questionnaire. Statistical analysis using Sperman Ranking. The results showed that $72 \%$ of patients had a high level, $23 \%$ had an intermediate level, and $5 \%$ had a high level. As many as $21 \%$ of $72 \%$ of patients with high participation rates managed to obtain remission while the rest were active. The results of statistical analysis showed that the adherence of the treatment of methotrexate was not significantly related to DAS 28 in AR patients $(r=0.148 ; p=0.169)$. However, remissions remain at a high level of compliance. The adherence of methotrexate therapy is still needed by AR patients to achieve remission conditions
\end{abstract}

\section{Pendahuluan}

Artritis reumatoid (AR) merupakan penyakit inflamasi sistemik progresif kronik yang menyerang pada sendi dan bagian lain dari tubuh. Salah satu ciri khas dari terjadinya AR yakni adanya eksaserbasi dan remisi dari aktivitas penyakitnya, sehingga dengan dibutuhkan pemantauan terapi jangka panjang untuk menghindari adanya disabilitas pada pasien AR. Diagnosis AR dilakukan dengan pemeriksaan dan assesment pada pasien yaitu bengkak yang disertai nyeri pada sendi 3 atau lebih, adanya keikutsertaan sendi metakarpal atau metatarsal yang disertai rasa membeku saat melakukan pergerakan, nyeri sendi pagi hari $>30$

* Corresponding author: Anisya Achmad, Jurusan Farmasi Fakultas Kedokteran ., Universitas Brawijaya, Jalan Veteran Malang. E-mail 3littleangels@ub.ac.id. 
menit, naiknya Erythrocyte Sedimentation Rate (ESR), Creactive Protein (CRP) dan Rheumatoid Factor (RF). ${ }^{1,2}$

Untuk mengetahui keberhasilan terapi yang diberikan kepada pasien, dibutuhkan suatu tindakan monitoring dan evaluasi terapi terkait pada keluhan, data klinik dan laboratorium serta data penunjang lain. Evaluasi terapi yang biasa dilakukan pada AR dapat berupa pemantauan aktivitas penyakit menggunakan Disease Activity Score 28 (DAS28). DAS28 merupakan alat pengukuran yang secara luas mudah diterima, diterapkan, dan digunakan.

DAS tidak hanya untuk tujuan penelitian secara klinik melainkan juga untuk penentuan keputusan terapetik dan prognosis. DAS28 mengkombinasikan jumlah sendi yang nyeri dan inflamasi guna mengukur tingkat kesehatan pasien dan fase akut reaktan. Pengukurannya berdasarkan pada 28 sendi yang mengalami nyeri dan inflamasi. ${ }^{3}$ Selain itu DAS28 lebih direkomendasikan pada penggunaan praktik klinik yang direkomendasikan oleh EULAR dan perhitungannya telah tervalidasi. ${ }^{4}$ Untuk mendapatkan hasil remisi pada DAS28 dibutuhkan terapi AR yang baik.

Terapi pengobatan lini pertama untuk AR adalah metotreksat. Metotreksat dan metabolitnya 7-hidroksimetotreksat diberikan kepada $70 \%$ pasien dengan pertimbangan yang setara antara resiko, keuntungan, keamanan, dan biaya yang murah. Metotreksat digunakan untuk monoterapi yang dapat mempertahankan remisi klinik atau juga bisa menggunakan terapi kombinasi dengan agen biologis. ${ }^{1}$ Hasil metabolisme metotreksat berupa poliglutamat bertanggung jawab atas kinerja sebagai antiinflamasi. Penggunaan metotreksat dapat menyebabkan efek samping baik secara akut ataupun kronis. Efek samping akut yang sering terjadi adalah nause, malaise dan muntah. Efek samping ini muncul setelah 1- 8 jam penggunaan dan berlangsung selama 1 minggu. Sedangkan efek samping stomatitis pada mukosa membran dan kulit terjadi sebanyak 12-37\% dan efek samping ini dapat menyebabkan ketidakpatuhan dalam terapi yaitu penghentian konsumsi metotreksat. ${ }^{1}$ Sehingga untuk meminimalisasi terjadinya hal ini maka perlu dipantau kepatuhan terapi pasien.

Kepatuhan menjadi salah satu faktor yang berkontribusi dalam efikasi terapi AR karena metotreksat baru memberikan efikasi setelah pengobatan dalam jangka waktu yang panjang. Pasien diharapkan konsisten dalam menjalankan pengobatannya melalui kontrol secara rutin maupun menerapkan frekuensi pemberian obat yang benar sehingga diharapkan peningkatan kepatuhan akan memberikan peningkatan kondisi remisi yang diukur dengan DAS28.

\section{Metode}

Penelitian dengan metode potong lintang analisis deskriptif kualitatif kuantitatif ini telah disetujui oleh komisi etik Rumah Sakit dr. Saiful Anwar Malang (RSSA) dengan nomor edaran 400/32/K.3/302/2018 dan dilakukan selama kurun waktu Maret-Mei 2018 di Poli Rawat Jalan Reumatologi. Peneliti menggunakan kuesioner kepatuhan Morinsky Medication Adherence Scale 8 (MMAS 8). Jumlah pasien sebanyak 88 orang yang diikutsertakan dalam penelitian setelah memenuhi kriteria inklusi dan setuju untuk menandatangani informed consent.
Kriteria Inklusi dan Eksklusi Pasien

Kriteria inklusi pasien dalam penelitian ini yakni berusia > 20 tahun baik laki-laki maupun perempuan yang telah didiagnosis menderita AR, menggunakan metotreksat oral tunggal minimal 3 bulan, pasien, tidak menggunakan NSAID ataupun metotreksat minimal 3 bulan, mempunyai data laboratorium laju endap darah (LED)/ Erythrocyte Sedimentation Rate (ESR) serta tanpa komplikasi penyakit lain seperti Systemic Lupus Erythematosus (SLE), Inflammatory Bowel Disease (IBD), dan kanker. Dosis metotreksat yang digunakan dalam penelitian ini dimulai dari terkecil yakni $5 \mathrm{mg}$ hingga dosis terbesar 17,5 mg. Kriteria eksklusi pasien adalah merokok dan/atau mengonsumsi alkohol.

Instrumen Penelitian

Peneliti menggunakan kuesioner kepatuhan Morinsky Medication Adherence Scale 8 (MMAS 8) dan dilakukan uji validitas dan reliabilitas pada 30 pasien dengan menggunakan aplikasi statistik SPSS 20.0 Uji validitas menggunakan metode Pearson Momen Product ( $\mathrm{r}>0,05)$ sedangkan uji reliabilitas menggunakan patokan nilai Cronbach Alpha dengan nilai $\alpha>0,6$. Pada kuesioner ini terdapat 8 pertanyaan dengan skoring " 0 " apabila menjawab "tidak" dan "1" apabila menjawab "ya". Selannjutnya peneliti menjumlahkan skoring dari 8 soal dengan interpretasi 1-2 dengan kepatuhan tinggi, 3-4 kepatuhan sedang, dan $>5$ kepatuhan rendah.

Instrumen untuk melihat kondisi penyakit digunakan DAS28. Perhitungan hasil skoring dari DAS28 menggunakan kalkulator matematik seperti keterangan di bawah ini 1 :

DAS28 $=0.56 \sqrt{ }($ TJC28 $)+0.28 \sqrt{ }($ SJC28 $)+0.70 \ln ($ LED $)+0.014$ $\mathrm{x}$ GH atau DAS28 $=0.56 \sqrt{ }(\mathrm{TJC} 28)+0.28 \sqrt{ }(\mathrm{SJC} 28)+$ $0.36 \ln (\mathrm{CRP}+1)+0.014 \times \mathrm{GH}+0.96$

Keterangan :

TJC $=$ nyeri tekan pada 28 sendi, SJC $=$ inflamasi pada 28 sendi, LED = laju endap darah dalam 1 jam pertama, GH = Patient's Assesment of General Health diukur dengan VAS (Visual Analog Score).

Tabel 1. Interpretasi Hasil DAS28-LED. 1

\begin{tabular}{|l|l|}
\hline Aktivitas Penyakit & Nilai DAS28-LED \\
\hline Remisi & $\leq 2,6$ \\
\hline Aktif Rendah & $>2,6 \mathrm{~s} / \mathrm{d} \leq 3,2$ \\
\hline Aktif Sedang & $>3,2 \mathrm{~s} / \mathrm{d} \leq 5,1$ \\
\hline Aktif Tinggi & $>5,1$ \\
\hline
\end{tabular}

\section{Hasil dan Diskusi}

Berdasarkan hasil penelitian didapatkan bahwa terdapat 14 pasien perempuan dan 74 pasien laki-laki yang telah didiagnosis menderita AR. Uji validitas kuesioner MMAS 8 menunjukkan hasil $r$ tabel sebesar 0,361 ( $r>0,05)$, sedangkan uji reliabilitas 
memberikan hasil signifikan $\alpha=0,838(\alpha>0,05)$. Hasil kuesioner MMAS 8 menunjukkan valid dan reliabel.

Tabel 2. Hasil Jawaban Kuesioner MMAS 28

\begin{tabular}{|c|c|c|c|}
\hline No & Pertanyaan & $\begin{array}{l}\text { Presentase } \\
\text { Jawaban "Ya" }\end{array}$ & $\begin{array}{l}\text { Presentase } \\
\text { Jawaban } \\
\text { Tidak" }\end{array}$ \\
\hline 1. & $\begin{array}{l}\text { Pernahkah Anda lupa } \\
\text { minum obat? }\end{array}$ & $26 \%$ & $74 \%$ \\
\hline 2. & $\begin{array}{l}\text { Apakah Anda pernah } \\
\text { tidak minum obat yang } \\
\text { diberikan membuat } \\
\text { Anda menjadi lebih } \\
\text { buruk? }\end{array}$ & $14 \%$ & $86 \%$ \\
\hline 3. & $\begin{array}{l}\text { Pernahkah } \\
\text { mengurangi anda } \\
\text { berhenti minum obat } \\
\text { tanpa sepengetahuan } \\
\text { dokter? }\end{array}$ & $19 \%$ & $81 \%$ \\
\hline 4. & $\begin{array}{l}\text { Pernahkah Anda lupa } \\
\text { membawa obat ketika } \\
\text { bepergian? }\end{array}$ & $14 \%$ & $86 \%$ \\
\hline 5. & $\begin{array}{l}\text { Apakah Anda masih } \\
\text { meminum obat Anda } \\
\text { kemarin? }\end{array}$ & $67 \%$ & $33 \%$ \\
\hline 6. & $\begin{array}{l}\text { Apakah Anda berhenti } \\
\text { meminum obat ketika } \\
\text { gejala teratasi? }\end{array}$ & $18 \%$ & $82 \%$ \\
\hline 7. & $\begin{array}{l}\text { Apakah Anda merasa } \\
\text { terganggu meminum } \\
\text { obat pada waktu yang } \\
\text { ditentukan? }\end{array}$ & $20 \%$ & $80 \%$ \\
\hline 8. & $\begin{array}{lr}\text { Apakah } & \text { Anda pernah } \\
\text { tidak minum obat } \\
\text { karena } & \text { kesulitan } \\
\text { mendapatkan obat? }\end{array}$ & $28 \%$ & $72 \%$ \\
\hline
\end{tabular}

Tabel 2 menyajikan pertanyaan kuesioner MMAS beserta hasil dari wawancara dengan pasien AR.. Pada pertanyaan 1 (lupa minum obat) didapatkan hasil sebesar $26 \%$ pasien pernah lupa meminum obat sedangkan $74 \%$ lainnya menjawab tidak.
Adanya variasi jawaban dari pasien dapat dipengaruhi oleh tingkat pengetahuan dan pendidikan pasien tentang penyakit AR namun peneliti tidak mengumpulkan data terkait hal tersebut. Penyakit AR membutuhkan waktu lama untuk mencapai target terapi karena pengobatan yang dilakukan dalam waktu jangka panjang. Beberapa pasien yang telah lama mengidap penyakit ini, mengetahui lebih banyak pengetahuan AR sehingga meskipun tanda-tanda telah berkurang konsistensi untuk meminum obat masih terus dilanjutkan. Hal ini dapat dihubungkan pada pertanyaan nomor 6 yaitu berkaitan dengan kesediaan pasien untuk tetap meminum obat meskipun gejala teratasi, dan didapatkan hasil berupa $18 \%$ menjawab "ya" dan $82 \%$ lainnya menghentikan meminum obat sewaktu gejala teratasi.

Pertanyaan pada nomor 2 dan 3 menyajikan hasil yang relevan dan berhubungan yaitu sebanyak $14 \%$ menjawab "ya" dan $86 \%$ lainnya menjawab "tidak" serta $19 \%$ menjawab "ya" dan $81 \%$ lainnya menjawab "tidak". Pasien mengatakan tidak mengalami efek yang buruk pada kesehatannya saat terlupa tidak meminum obat. Hal ini berkaitan dengan pernyataan sebanyak $81 \%$ pasien yang tidak menghentikan pengobatan metotreksat karena tidak terjadi efek yang buruk pada kesehatannya. Efek buruk yang dimaksud adalah efek samping metotreksat yaitu nausea, malaise, muntah , pusing mucositis, efek samping pada sistem pernafasan, saraf pusat, hematologi, tulang, ginjal dan hati. ${ }^{5}$ Penyebabnya diduga adalah akumulasi dari metotreksat poliglutamat yang berakumulasi pada sel mukosa intestinal. ${ }^{6}$

Pertanyaan selanjutnya mengenai ketepatan pasien untuk membawa obatnya sewaktu bepergian didapatkan hasil $14 \%$ menjawab "ya" dan $86 \%$ menjawab tidak. Bepergian dalam hal ini adalah pasien keluar rumah dengan jangka waktu melewati saat minum obat. Sebanyak $14 \%$ pasien lupa membawa obat namun waktu bepergian tidak termasuk dalam jadwal meminum obat. Seandainya jadwal minum obat terlupa, maka pasien akan meminumnya di keesokan hari. Pertanyaan selanjutnya pada nomor 5 'apakah masih tetap konsisten meminum obatnya?'. Perlu diketahui bahwa kata "kemarin" dalam konteks pertanyaan ini adalah pasien masih meminum obatnya sesuai dengan jadwal yaitu satu minggu sekali. Berdasarkan hasil wawancara ini didapatkan $67 \%$ pasien menjawab "ya" dan $33 \%$ pasien yang menjawab tidak. Jawaban pertanyaan ini dapat dihubungkan dengan pertanyaan nomor 8 berkaitan dengan kemudahan pasien dalam mendapatkan obat. Kontribusi atas ketersediaan obat di apotek rumah sakit sangat berperan dalam kemudahan pasien meminum obat. Sehingga jadwal meminum obat tepat waktu tidak bergeser mengikuti ketersediaan obat metotreksat di apotek rumah sakit. Hasil pertanyaan no 8 adalah $28 \%$ pasien merasa kesulitan mendapatkan obat.

Tabel 3. Tabel 3. 
Persebaran Aktivitas Penyakit Artritis Rheumatoid terhadap Tingkat Kepatuhan

Persebaran aktivitas penyakit artritis reumatoid, terhadap tingkat kepatuhan disajikan dalam bentuk tabel (tabel 3) dan didapatkan aktivitas penyakit

DAS28 remisi sebanyak 16 pasien dengan tingkat kepatuhan bervariasi, 13 dari 16 pasien memiliki kepatuhan tinggi sedangkan 3 dari 16 pasien memiliki kepatuhan sedang. Adapun terdapat 15 pasien pada aktivitas penyakit aktif rendah dengan tingkat kepatuhan tinggi sebanyak 11 orang dan kepatuhan sedang pada 4 orang. Aktivitas penyakit sedang mempunyai jumlah pasien paling banyak yakni sebanyak 54 pasien dan didapatkan 5 dari 54 pasien mempunyai tingkat kepatuhan rendah.

Meskipun bekerja dalam jangka waktu panjang, metotreksat sebagai antiinflamasi pada artritis reumatoid begitu pula metabolitnya 7-hidroksi metotreksat sebenarnya mempunyai waktu paruh kurang dari 8 jam untuk metotreksat dan kurang dari 12 jam untuk 7-hidroksi metotreksat hingga akhirnya tidak terdeteksi setelah 24-52 jam. Hasil metabolisme metotreksat berupa poliglutamat bertanggung jawab atas kinerja sebagai antiinflamasi. $^{6}$

Dosis yang biasa digunakan untuk artritis reumatoid berada pada rentang 7,5-25 $\mathrm{mg} /$ minggu meskipun pemberian dosis ini didasarkan pada tolerabilitas pasien sewaktu pengobatan. Namun pada penelitian ini, dosis minimal metotreksat adalah $5 \mathrm{mg}$ dan maksimal $17,5 \mathrm{mg}$. Pemberian dosis metotreksat pada pasien diputuskan oleh dokter, salah satu pertimbangannya adalah pasien telah menerima terapi metotreksat lebih dari 3 bulan. Pemberian jangka panjang metotreksat dikuatirkan terjadi kejenuhan reseptor yang menyebabkan minimalnya absorbsi dan meningkatnya efek samping. Terapi metotreksat biasa diberikan seumur hidup karena AR merupakan penyakit autoimun namun semuanya tergantung dari kondisi pasien. Bioavailabilitas pada pemberian oral dosis rendah untuk terapi AR hanya mencapai rentang $60-70 \%$, meskipun terdapat variabilitas pada setiap individu. ${ }^{6}$ Pola penggunaan metotreksat pada pasien AR untuk penelitian ini menunjukkan bahwa dosis maksimum $25 \mathrm{mg}$ masih belum tercapai. Kenaikan dosis sebesar 2,5-5 mg setiap 2-4 minggu sekali sebagai upaya optimalisasi efikasi pengobatan kemungkinan tidak dilakukan. Hasil penelitian menunjukkan dosis awal yang biasa diberikan sebesar $7,5 \mathrm{mg} / \mathrm{minggu}$ dinilai kurang efektif dan pada beberapa kasus membutuhkan kenaikan dosis setelah 6 bulan terapi, dimulai dari dosis yang diterima 12,5-20 mg/minggu dinilai lebih efektif dibandingkan dengan 5$7,5 \mathrm{mg} / \mathrm{minggu}$. Hasil systematic review merekomendasikan pemberian dosis optimal berkisar pada $10-15 \mathrm{mg} / \mathrm{minggu}$ melalui pemberian oral serta pertimbangan pada kondisi fisik pasien. ${ }^{8}$

\begin{tabular}{|l|l|l|l|l|}
\hline \multirow{2}{*}{$\begin{array}{l}\text { Aktivitas } \\
\text { AR }\end{array}$} & \multirow{2}{*}{$\begin{array}{l}\text { Jumlah } \\
\text { Pasien }\end{array}$} & \multicolumn{3}{|l|}{ Tingkat Kepatuhan } \\
\cline { 3 - 5 } & & Tinggi & Sedang & Rendah \\
\hline Remisi & 16 & 13 & 3 & - \\
\hline $\begin{array}{l}\text { Aktif } \\
\text { Rendah }\end{array}$ & 15 & 11 & 4 & - \\
\hline $\begin{array}{l}\text { Aktif } \\
\text { Sedang }\end{array}$ & 54 & 39 & 10 & 5 \\
\hline $\begin{array}{l}\text { Aktif } \\
\text { Tinggi }\end{array}$ & 3 & - & 3 & - \\
\hline N & 88 & 63 & 20 & 5 \\
\hline
\end{tabular}

itu kejadian morning stiffness, nyeri, dan kaku sendi biasa muncul pada pagi hari berhubungan dengan meningkatnya sitokin proinflamasi. Sehingga pemberian terbaik untuk metotreksat dapat digunakan pada malam hari sebelum tidur. Terapi pengobatan yang tidak sesuai dengan frekuensi dan waktu pemberian, dapat memberikan efek antiinflamasi yang berbeda karena perbedaan kadar obat dalam plasma disaat pengukuran DAS28. Melalui penjelasan diatas, efikasi metotreksat melalui remisi DAS28 bergantung pada dosis, frekuensi dan waktu penggunaan yang tepat. Dosis lazim yang diberikan untuk pemberian awal metotreksat yaitu 7,5 mg satu kali/minggu kemudian bsia ditingkatkan dosisnya hingga 25-30 mg pada minggu selanjutnya untuk mencapai respon klinik yang lebih baik. ${ }^{9,10}$ Peningkatan dosis dapat dilakukan selama interval waktu 2-4 minggu tergantung pada toleransi dan respons pasien dalam pengobatan. ${ }^{8}$

Tabel 4. Analisa Hasil Uji Korelasi Kepatuhan dengan Skoring DAS28

\begin{tabular}{|l|l|l|l|}
\hline \multirow{2}{*}{} & \multicolumn{2}{|l|}{ DAS28 } \\
\cline { 2 - 4 } & $\mathrm{R}$ & $\mathrm{P}$ & $\mathrm{N}$ \\
\hline Kepatuhan & 0,148 & 0,169 & 88 \\
\hline
\end{tabular}


Berdasarkan uji statistic (table 4), tidak ada hubungan yang signifikan antara kepatuhan dan DAS28 dengan tingkat hubungan lemah. Hal ini dikarenakan faktor lain dari kepatuhan seperti umur, jenis kelamin, pengetahuan, penghasilan dan pendidikan pasien tidak diteliti. Selain itu kondisi fiisik pasien tidak sama dalam menerima terapi metotreksat. Namun kepatuhan yang tinggi pada pengobatan dapat menghasilkan efek remisi melalui pengukuran DAS28. Melalui penelitian ini diharapkan ada implementasi klinik berupa konseling terapi metotreksat pada pasien AR

4. Daftar Pustaka

1. Indonesian Rheumatology Association. Diagnosis and Management of Rheumatoid Arthritis (RA), Jakarta, Indonesian Rheumatology Association; 2014.

2. American College of Rheumatology Subcommittee on Rheumatoid Arthritis. Guidelines for the management of rheumatoid arthritis. Arthritis Rheum, 2002, 46(2):328-346.

3. Castrejón I., Ortiz A., Toledano E., et al. Estimated Cutoff Points For The 28-Joint Disease Activity Score Based On CReactive Protein In A Longitudinal Register Of Early Arthritis. J Rheumatol. 2010, 37:1439-1443.

4. Fransen, Jaap., Van Riel, Piet L.C.M. The Disease Activity Score and the EULAR Response Criteria. Rheum Dis Clin N Am. 2009, 35, 745-757.

5. Koehnke R., Burmeister L.F., Kohler J., and Cargill I. Increasing methotrexate effect with increasing dose in the treatment of resistant rheumatoid arthritis. J Rheumatol, 2011(16) :313-20.

6. Firestein Gary S., Budd Ralph C., Gabriel Sherine E., McInnes Iain B., and O'dell James R. Textbook of Rheumatology. Elsevier. Philadelphia; 2017.

7. Danila, M. I., Hughes, L. B., Brown, E. E., Morgan, S. L., Baggott, J. E., Arnett, D. K. and Bridges, S. L. Measurement Of Erythrocyte Methotrexate Polyglutamate Levels: Ready For Clinical Use In Rheumatoid Arthritis. Curr. Rheumatol. Rep. 2010, 12: 342-347.

8. Van Nies J.A., De Jong Z., Vander Helm, Van Mil A.H., et al. Improved Treatment Strategies Reduce The Increased Mortality Risk In Early RA Patients. Rheumatology (Oxford). 2010, 49:2210-2216. 36.

9. Singh J.A., Furst D.E., Bharat A., Curtis J.R., Kavanaugh A.F., Kremer J.M., et al. Update Of The 2008 American College Of Rheumatology Recommendations For The Use Of Disease - Modifying Antirheumatic Drugs And Biologic Agents In The Treatment Of Rheumatoid Arthritis. Arthritis Care Res. 2012, 64:625-39.

10. Smolen J.S., et al. EULAR Recommendations For The Management Of Rheumatoid Arthritis With Synthetic And Biological Disease modifying Antirheumatic Drugs: 2013 Update. Ann Rheum Dis. 2014;, 3:492-509. 